\title{
Magnitude and associated factors for attitude and practice of Southern Ethiopian residents toward COVID-19 and its preventions: A community based cross sectional study
}

Simeneh Mola ( $\nabla$ ksimenehmola@yahoo.com )

Dilla University https://orcid.org/0000-0001-5797-1869

\section{Zemedu Aweke}

Dilla University

Bedru Jemal

Dilla University

Robel Hussein

Dilla University

Sileshi Hailu

Dilla University

Derartu Neme

Dilla University

Hailemariam Mulugeta

Dilla University

Abebayehu Zemedkun

Dilla University

Research Article

Keywords: COVID-19, Attitude, Practice, Associated factors, Southern Ethiopia

Posted Date: June 22nd, 2020

DOI: https://doi.org/10.21203/rs.3.rs-36120/v1

License: (c) (i) This work is licensed under a Creative Commons Attribution 4.0 International License.

Read Full License 


\section{Abstract}

Background: COVID-19 first broke out in china, Hubei province on December 29, 2019. Since then it took more than hundred thousand lives worldwide. Although all countries are taking varying degree of measures to curb the dissemination, the virus is still spreading rapidly in all part of the world. Adherence of peoples for COVID-19 precautions measures is one of the most important factors which determine the effectiveness of curbing the spread. However without having good attitude adherence of people toward precaution measures could be challenging. Therefore the aim of this study is to assess the attitude, practice and associated factors of southern Ethiopian residents toward COVID-19 and its prevention.

Methods: A community based cross sectional study was conducted among 585 Southern Ethiopian residents. Bivariate and multivariate binary logistic regression was used to determine association between dependent and independent variables. Adjusted odds ratio with their $95 \% \mathrm{Cl}$ was used show the strength of association. P-value $<0.05$ was used to decide statistically significant association.

Result: Most of the study participants (90.3\%) have good attitude toward COVID-19 and its prevention. Being younger age group, having chronic medical illness, using television as a source of information and having good knowledge were significantly associated with good attitude toward COVID-19.On other hand; only $20 \%$ of the study participants have good practice toward COVID-19 prevention. Educational status, occupation and having chronic medical illness, uses of religious teaching as information sources are associated factors for good practice against COVID-19 infection.

Conclusion: We conclude that despite the presence good attitude in majority of respondents much work needed to improve rare practice of COVID-19 preventive measures.

\section{Background}

The coronavirus disease 19 (COVID-19) is an extremely contagious viral infection caused by severe acute respiratory syndrome corona virus 2 (SARS-CoV-2) and first broke out in china, Hubei province, on December 29, 2019[1][2].

To date, June 7, 2020, about 7 million confirmed cases and 400, 000 deaths have been reported worldwide [3]. Yet the number of positive cases and deaths continues to rise rapidly. Difficulty of isolating suspected cases due to long incubation period and its rapid contagiousness makes the diseases challenging to control. The virus can also present in some peoples with few or no symptoms, which makes the spreading quicker and silent[1]. Consequently even developed nations like USA, Italy, Spain, France and China are severely affected by the outbreak [3].

So far African continent has reported relatively lesser number of cases $(131,324)$ and deaths $(3,148)[4]$. There is a debate on the reason for lower number of cases and deaths. Some of speculations are 
relatively lower testing rates, poor reporting habits and lower number of passengers coming to continents [5-8]. However nothing can spare Africa from casualty but preparation and on time response. In addition there is a concern from world health organization (WHO) that the disease could spread rapidly and causes devastating causalities in most African countries where it is difficult to exercise COVID-19 precaution measures[8].

Since the start of the outbreak, Ethiopian government has been taking different measures to tackle the spread based on WHO recommendations, starting from surveillance of people coming from aboard at the airport or border line[9] to varying levels of contact tracing and isolation and quarantine of suspected cases; Awareness creations are also being given by different means such as television, radio, telecommunication and social media in order to encourage peoples for hand washing, respiratory hygiene, social distancing and avoid hand shaking and public gathering[10].

Resources are also being mobilized from the citizens and foreign donors besides preparation of health systems for possible upcoming overwhelms of hospitals by severely ill patients who require isolation, oxygen, and mechanical ventilation[11].

In addition to government effort, people's adherence for preventive measures is vital to accomplish a success against the ongoing fight of COVID-19 pandemics. However, in the absence of good attitude in a community toward COVID-19, adherence for prevention measures could be challenging. Therefore the aim of this study is to assess the attitude, practice and associated factors of southern Ethiopian residents toward COVID-19 and its prevention.

\section{Methods}

A community based cross sectional study was conducted on between March 27 to 31, 2020 to assess attitude, practice and associated factors of southern Ethiopia residents towards COVID-19 and its preventions. Face to face interview was conducted among 585 Southern Ethiopian adult's residents. Sample size was calculated based on the fact that no similar study had conducted during the study period, so $p$ and q were considered as 0.5 and margin of error 0.4 with $95 \%$ confidence interval. By using single proportion formula sample size were determined to be 600 .

There were about 9 (nine) attitude questions. All nine questions use likert scale measurement. Each questions scored out of 5 , making the total maximum score 45 and the minimum 9 . Those participants who scored below 25 points on all nine questions were considered as they have poor attitude and those who scored 25 and above were considered as they have good attitude.

Practice assessed by 8 questions in likert scale and each scored up to $2(0=$ disagree, $1=$ neutral, $2=$ agree) and the overall maximum score being 16 and the minimum score 0. Overall Score below 8 was considered as poor practice and, 8 and above as good practice. 
Questions were prepared in English and translated to local languages 'Amharic' and 'gedeu'ffa'. Questionnaires were filled by trained data collectors. Socio-demographic factors such as age, gender, marital status, education, occupation, religion, residence, sources of information, household size ...etc were collected as independent variables.

Data were coded and entered in to Epi-data 3.1 and were exported into SPSS version 25 for cleaning and analysis. Frequency tables, and descriptive summaries were used to describe the study variables. Bivariate binary logistic regression analysis was used to see the crude association between dependent and independent variables. All explanatory variables which had association in bivariate analysis at pvalue less than or equal to 0.25 were entered into multivariable binary logistic regression model. Multicollinearity was checked by variance inflation factor and tolerance level. Adjusted odds ratio with their $95 \% \mathrm{Cl}$ was used to show the strength association. P-value $<0.05$ was used to declare statistical significance of independent predictors.

\section{Result}

\section{Socio-demographic characteristics of respondents}

From a total of 600 eligible respondents, 585 were analyzed and the rest of 15 were excluded due to lack of cleanness and incompleteness of the data. The mean age of the respondents was 33.7 with a standard deviation of \pm 11 . About $41.9 \%$ of the study participants were female and $12.5 \%$ have no any formal education. Majority (74.4\%) of study participants were married and nearly half $(54.4 \%)$ of the respondents live in rural area. The socio-demographic characteristics of respondent were shown in Table1. 
Table 1

Sociodemographic characteristics

\begin{tabular}{|c|c|c|c|}
\hline \multicolumn{2}{|l|}{ Variables } & \multirow{2}{*}{$\begin{array}{l}\text { Frequency } \\
493\end{array}$} & \multirow{2}{*}{$\begin{array}{l}\text { Percentage (\%) } \\
84.3\end{array}$} \\
\hline Age & $18-45$ & & \\
\hline & $45-60$ & 81 & 13.8 \\
\hline & $>=60$ & 11 & 1.9 \\
\hline \multirow[t]{2}{*}{ Gender } & Male & 340 & 58.1 \\
\hline & Female & 245 & 41.9 \\
\hline \multirow[t]{4}{*}{ Education } & No formal education & 73 & 12.5 \\
\hline & Primary school (1-8) & 208 & 35.6 \\
\hline & Secondary (9-12) & 176 & 30.1 \\
\hline & Above & 128 & 21.9 \\
\hline \multirow[t]{4}{*}{ Marital status } & Married & 435 & 74.4 \\
\hline & Not married & 121 & 20.7 \\
\hline & Divorced & 17 & 2.9 \\
\hline & Widowed & 12 & 2.0 \\
\hline \multirow[t]{2}{*}{ Residence } & Urban & 266 & 45.5 \\
\hline & Rural & 319 & 54.5 \\
\hline \multirow[t]{2}{*}{ Family size } & $>5$ & 313 & 53.5 \\
\hline & $<=5$ & 272 & 46.5 \\
\hline \multirow[t]{4}{*}{ Religion } & Orthodox & 208 & 35.6 \\
\hline & Catholic & 19 & 3.2 \\
\hline & Protestant & 296 & 50.6 \\
\hline & Muslim & 62 & 10.6 \\
\hline \multirow[t]{5}{*}{ Occupation } & Farmer & 73 & 12.5 \\
\hline & Merchant & 155 & 26.5 \\
\hline & Government employee & 116 & 19.8 \\
\hline & Daily laborer & 47 & 8 \\
\hline & House wife & 111 & 19.0 \\
\hline
\end{tabular}




\begin{tabular}{|llll|}
\hline Variables & & Frequency & Percentage (\%) \\
\hline & Other $^{1}$ & 83 & 14.2 \\
\hline
\end{tabular}

\section{Attitude toward covd-19 and its prevention}

Nine questions, each question possesses five points, were used to assess the attitude of respondents. The mean score of respondents was 34.45 ( \pm SD 5.5) and eighteen and forty five were the minimum and maximum scores respectively. By using 25 point as a cut point, only $9.7 \%$ of the respondents scored below 25 points but majority of participants (90.3) have favorable attitude toward covid-19 and its prevention. From all respondents $67 \%$ of participants strongly or very strongly believe that covid- 19 is curse and about quarter (23.9\%) of participants strongly or very strongly believe that the virus could not be transmitted in hot climate. Only $5 \%$ respondent not worried at all about COVID- 19 and $2 \%$ consider it as common cold and the rest $93 \%$ are worried moderately, very worried or most worried about covid-19 infection.

\section{Practice toward covid-19 and its prevention}

Majority of respondent (80\%) have bad practice toward covid-19 prevention. Almost all respondent (93.3\%) never used surgical mask. However more than halve of respondents $(58.3 \%)$ had been practicing hand washing using soap more than 3 times a day and $38.1 \%$ one or two times a day the rest not practiced hand washing using soap in a day. About $43.1 \%$ participants were practicing hand shaking and only $10 \%$ of participants were practicing social distancing but the rest $61.4 \%$ and $28.3 \%$ were never practiced social distancing or sometimes practiced social distancing respectively.

\section{Associated factors for attitude toward covid-19 and its preventions}

On multivariate analysis we found that the being age group between $18-44.9$ years (AOR: $3.82: 95 \% \mathrm{Cl}$ (1.764-19.068)], having chronic medical illness [AOR: 2.73: 95\% $\mathrm{Cl}(1.01-7.44))$, use of television as a source of information [AOR: 2.65: $95 \% \mathrm{Cl}(1.27-5.54)$ ] and having good knowledge about COVID-19 [AOR:2.05: $95 \% \mathrm{Cl}$ (1.05-4.00)] have significant association with good attitude( shown on Table 2) . 
Table 2

Associated factors for level of attitude

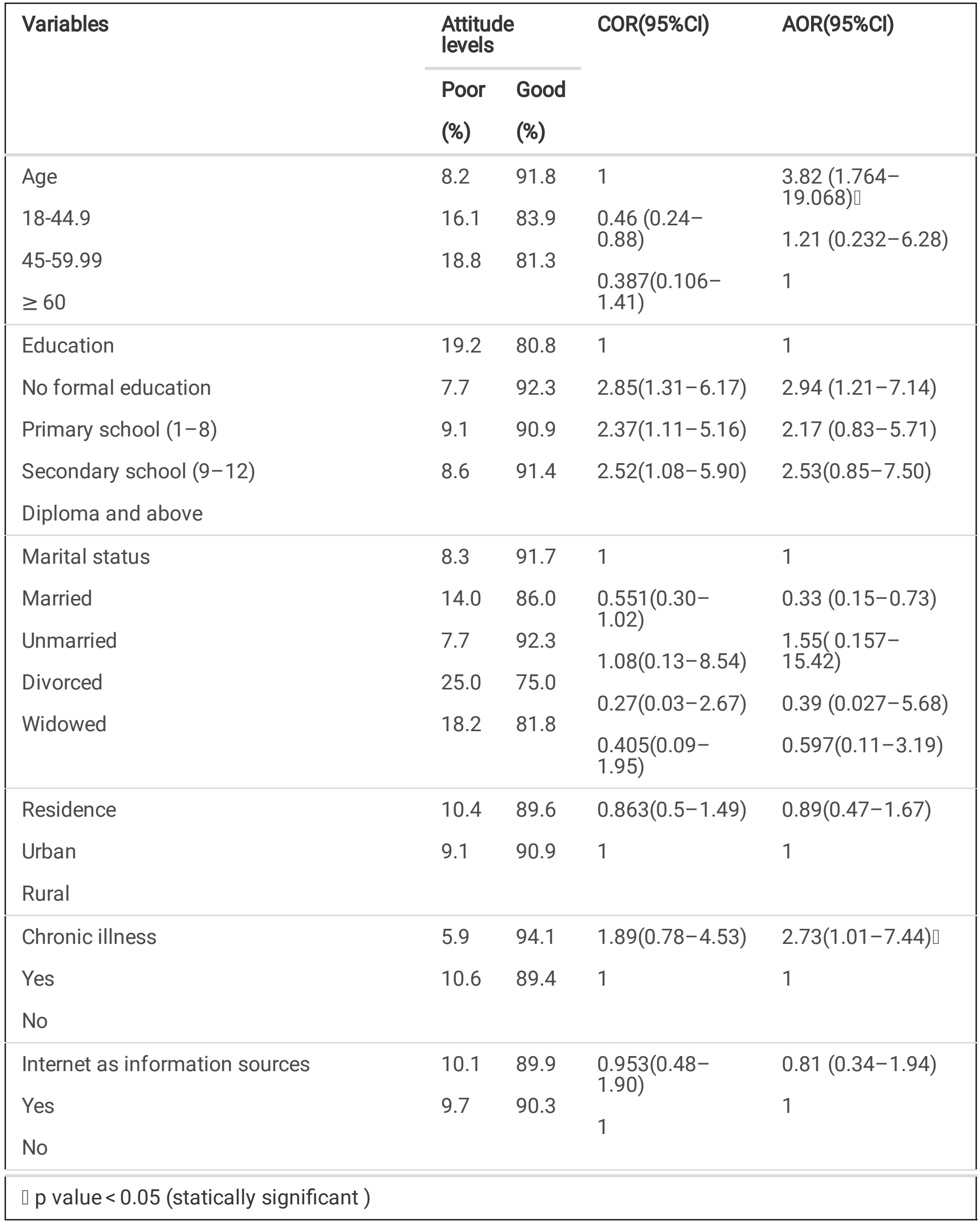




\begin{tabular}{|c|c|c|c|c|}
\hline \multirow[t]{3}{*}{ Variables } & \multicolumn{2}{|c|}{$\begin{array}{l}\text { Attitude } \\
\text { levels }\end{array}$} & \multirow[t]{3}{*}{$\operatorname{COR}(95 \% \mathrm{Cl})$} & \multirow[t]{3}{*}{$\mathrm{AOR}(95 \% \mathrm{Cl})$} \\
\hline & Poor & Good & & \\
\hline & (\%) & (\%) & & \\
\hline \multirow{3}{*}{$\begin{array}{l}\text { Television/Radio as information sources } \\
\text { Yes } \\
\text { No }\end{array}$} & 8.0 & 92.0 & \multirow{2}{*}{$\begin{array}{l}2.97(1.59- \\
5.549)\end{array}$} & $2.65(1.27-5.54) \square$ \\
\hline & \multirow[t]{2}{*}{20.5} & \multirow[t]{2}{*}{79.5} & & 1 \\
\hline & & & & \\
\hline \multirow{2}{*}{$\begin{array}{l}\text { Telecommunication as sources of } \\
\text { information }\end{array}$} & 9.5 & 90.5 & $1.00(0.62-1.86)$ & $0.657(0.34-1.28)$ \\
\hline & 10.1 & 89.9 & 1 & 1 \\
\hline \multicolumn{5}{|l|}{ yes } \\
\hline \multicolumn{5}{|l|}{ No } \\
\hline \multirow{2}{*}{$\begin{array}{l}\text { Religious teaching as sources of } \\
\text { information }\end{array}$} & 15.2 & 84.8 & $0.57(0.24-1.34)$ & $0.544(0.21-1.40)$ \\
\hline & 9.3 & 90.7 & 1 & 1 \\
\hline \multicolumn{5}{|l|}{ Yes } \\
\hline \multicolumn{5}{|l|}{ No } \\
\hline पp value $<0.05$ (statically significant ) & & & & \\
\hline
\end{tabular}

\section{Associated factors for practice toward covid-19 and its preventions}

The presences of chronic illness, occupation and uses of religious places as a source of information and educational status have association with practice toward covid-19 prevention. As shown on Table 3 , peoples who have chronic medical illness are 1.88 times more likely to have good practices [AOR $=1.883$, $95 \% \mathrm{Cl}: 1.044-3.395]$. Being merchant or government employees increases the likelihood of good practice compared to farmers by 3 and 2 times respectively. Those persons who have above secondary school educational level are around 7 times more likely [AOR $=6.903,95 \% \mathrm{Cl}$ : 2.094-22.756] to have good practice than persons who have no formal education. 
Table 3

Associated factors for level of practice

\begin{tabular}{|c|c|c|c|c|c|}
\hline \multirow[t]{2}{*}{ Variables } & & \multicolumn{2}{|l|}{ Practice } & \multirow[t]{2}{*}{$\begin{array}{l}\text { AOR }(95 \% \\
\text { C.I. })\end{array}$} & \multirow[t]{2}{*}{$\begin{array}{l}\mathrm{P} \text { - } \\
\text { value }\end{array}$} \\
\hline & & Poor & Good & & \\
\hline \multirow[t]{3}{*}{ Age } & $18-45$ & $79.4 \%$ & $20.6 \%$ & 1 & \multirow[t]{3}{*}{0.157} \\
\hline & $45-60$ & $86.0 \%$ & $14.0 \%$ & $\begin{array}{l}0.871(0.422- \\
1.799)\end{array}$ & \\
\hline & $>=60$ & $62.5 \%$ & $37.5 \%$ & $\begin{array}{l}3.611(0.891- \\
14.632)\end{array}$ & \\
\hline \multirow[t]{4}{*}{ Educational status } & $\begin{array}{l}\text { No formal } \\
\text { education }\end{array}$ & $87.7 \%$ & $12.3 \%$ & 1 & \multirow[t]{4}{*}{0.003} \\
\hline & $\begin{array}{l}\text { Primary school } \\
(1-8)\end{array}$ & $87.5 \%$ & $12.5 \%$ & $\begin{array}{l}1.764(0.658- \\
4.730)\end{array}$ & \\
\hline & $\begin{array}{l}\text { Secondary (9- } \\
12)\end{array}$ & $75.0 \%$ & $25.0 \%$ & $\begin{array}{l}3.976(1.386- \\
11.402)\end{array}$ & \\
\hline & Above & $70.3 \%$ & $29.7 \%$ & $\begin{array}{l}6.903(2.094- \\
22.756)\end{array}$ & \\
\hline \multirow[t]{5}{*}{ Religion } & Orthodox & $71.6 \%$ & $28.4 \%$ & 1 & \multirow[t]{5}{*}{0.146} \\
\hline & Catholic & $94.7 \%$ & $5.3 \%$ & $\begin{array}{l}0.210(0.026- \\
1.705)\end{array}$ & \\
\hline & Protestant & $86.1 \%$ & $13.9 \%$ & $\begin{array}{l}0.588(0.356- \\
0.970)\end{array}$ & \\
\hline & Muslim & $73.8 \%$ & $26.2 \%$ & $\begin{array}{l}1.101(0.533- \\
2.275)\end{array}$ & \\
\hline & Other & $100.0 \%$ & 0 & $0.0(0.0-0.0)$ & \\
\hline \multirow[t]{5}{*}{ Occupation } & Farmer & $94.5 \%$ & $5.5 \%$ & 1 & \multirow[t]{5}{*}{0.015} \\
\hline & Merchant & $81.9 \%$ & $18.1 \%$ & $\begin{array}{l}3.006(0.862- \\
10.479)\end{array}$ & \\
\hline & $\begin{array}{l}\text { Government } \\
\text { employee }\end{array}$ & $75.9 \%$ & $24.1 \%$ & $\begin{array}{l}2.248(0.596- \\
8.476)\end{array}$ & \\
\hline & Daily laborer & $95.7 \%$ & $4.3 \%$ & $\begin{array}{l}0.796(0.126- \\
5.045)\end{array}$ & \\
\hline & House wife & $73.0 \%$ & $27.0 \%$ & $\begin{array}{l}5.548(1.644- \\
18.720)\end{array}$ & \\
\hline
\end{tabular}




\begin{tabular}{|c|c|c|c|c|c|}
\hline \multirow[t]{2}{*}{ Variables } & \multirow[b]{2}{*}{ Other ${ }^{1}$} & \multicolumn{2}{|l|}{ Practice } & \multirow{2}{*}{$\begin{array}{l}\text { AOR }(95 \% \\
\text { C.I.) } \\
3.539(0.930- \\
13.463)\end{array}$} & \multirow{2}{*}{$\begin{array}{l}P \text { - } \\
\text { value }\end{array}$} \\
\hline & & $69.9 \%$ & $30.1 \%$ & & \\
\hline \multirow[t]{4}{*}{ Marital status } & Married & $81.7 \%$ & $18.3 \%$ & 1 & \multirow[t]{4}{*}{0.937} \\
\hline & Not married & $70.2 \%$ & $29.8 \%$ & $\begin{array}{l}1.125(0.583- \\
2.172)\end{array}$ & \\
\hline & Divorced & $100.0 \%$ & 0.0 & $\begin{array}{l}0.0(0.00- \\
0.00)\end{array}$ & \\
\hline & Widowed & $90.9 \%$ & $9.1 \%$ & $\begin{array}{l}0.405(0.046- \\
3.561)\end{array}$ & \\
\hline \multirow[t]{2}{*}{ Travel history } & Yes & $72.5 \%$ & $27.5 \%$ & $\begin{array}{l}1.255(0.741- \\
2.124)\end{array}$ & \multirow[t]{2}{*}{0.398} \\
\hline & No & $82.4 \%$ & $17.6 \%$ & 1 & \\
\hline \multirow[t]{2}{*}{ Residence } & Urban & $81.7 \%$ & $18.3 \%$ & $\begin{array}{l}0.680(0.411- \\
1.126)\end{array}$ & \multirow[t]{2}{*}{0.134} \\
\hline & Rural & $78.1 \%$ & $21.9 \%$ & 1 & \\
\hline \multirow[t]{2}{*}{ Chronic illness } & Yes & $67.6 \%$ & $32.4 \%$ & $\begin{array}{l}1.883(1.044- \\
3.395)\end{array}$ & \multirow[t]{2}{*}{0.035} \\
\hline & No & $82.6 \%$ & $17.4 \%$ & 1 & \\
\hline \multirow[t]{2}{*}{ Internet source of information } & Yes & $69.7 \%$ & $30.3 \%$ & $\begin{array}{l}1.216(0.668- \\
2.214)\end{array}$ & \multirow[t]{2}{*}{0.522} \\
\hline & No & $82.4 \%$ & $17.6 \%$ & 1 & \\
\hline \multirow[t]{2}{*}{ Television source of information } & Yes & $79.1 \%$ & $20.9 \%$ & $\begin{array}{l}1.108(0.516- \\
2.377)\end{array}$ & \multirow[t]{2}{*}{0.792} \\
\hline & No & $85.5 \%$ & $14.5 \%$ & 1 & \\
\hline \multirow[t]{2}{*}{$\begin{array}{l}\text { Telecommunication source of } \\
\text { information }\end{array}$} & Yes & $83.8 \%$ & $16.2 \%$ & $\begin{array}{l}0.20(0.316- \\
1.857)\end{array}$ & \multirow[t]{2}{*}{0.101} \\
\hline & No & $75.1 \%$ & $24.9 \%$ & 1 & \\
\hline \multirow[t]{2}{*}{$\begin{array}{l}\text { Religious teaching as a source of } \\
\text { information }\end{array}$} & Yes & $91.3 \%$ & $8.7 \%$ & $\begin{array}{l}0.256(0.082- \\
0.799)\end{array}$ & \multirow[t]{2}{*}{0.019} \\
\hline & No & $79.0 \%$ & $21.0 \%$ & 1 & \\
\hline
\end{tabular}

\section{Discussion}


This study was conducted 2 weeks after the first confirmed covid-19 case (March 13) in Ethiopia. At the time of data collection there were 16 confirmed covid-19 cases but no death[12]. We investigated the attitude, practice and associated factors of southern Ethiopian residents toward covid-19 and its preventions.

On the present study, most of the study participant (90.3\%) have good attitude toward covid-19 and its prevention. This finding is consistent with study done in Iran though it is by far higher compared to the study done in Thailand[13] which showed $61.5 \%$ of populations have good attitude toward COVID-19 and its prevention. The difference could be due to the fact that our study conducted later than the study of Thailand. In between period of two studies so many fatality and crises happened around the world which can change the perception and attitude of mankind toward COVID-19 and its prevention.

This study also reveals that being younger age, having chronic medical illness, using television as a source of information and having good knowledge about COVID-19 were associated factors which increase the likelihood to have good attitude. Similarly study done in Thailand[13] showed peoples who have medical illness were more likely to have good attitude. Surprisingly in our study elder population have relatively poor attitude despite being more vulnerable for complications of COVID-19 infection. In contrast A. Erfani et al. [14]demonstrated that older age groups have higher likelihood to have good attitude. The difference could be due to elders in our country see such kind of events either traditionally or spiritually perspectives.

Practicing preventive measures like frequent hand washing using soap, uses of sanitizer, avoidance of hand shaking and public gathering and use of face mask are paramount important for mitigating the spread of COVID-19 infection[15]. However, our result showed that only $20 \%$ of the populations are practicing prevention measures favorably. For example only $6.3 \%$ of participants had worn face mask when leaving home. Comparing with the reports of Peeradone et al, in Taiwan,[10] and Azlan A.A. et al. in Malaysia[16] in which there was $98 \%$ and $51 \%$ practice of using face mask ; our respondents have by far lower experience of using face mask. This huge variation can be explained primarily by scarcity of protective equipment at national level. In addition peoples in our country were discouraged to use medical face mask so that it can be saved to be used by health care providers.

In addition to lower rate face mask user, social distancing had practiced by only $10 \%$ participants which was much lower than the finding of a study conducted by John M Clements et al, USA, which was $70 \%$ peoples avoid mass gathering[17]. The difference might be due two major reasons; firstly, the variation of number of reported cases and fatality in two nations at a time of data collection; secondly, difference of two country's peoples in capacity to cop up economic burden of social distancing. On other hand majority of our participants avoid hand shaking (56\%) and frequently practicing hand washing using soap (58.6\%). These two practices relatively received better acceptance by the community. This might be due to they are relatively cheaper tasks to exercise. However, in a comparison to other developing nations like Bangladesh[18] in which there is $98.6 \%$ hand washing practice our finding revealed a huge gap in the study area. 
Educational status ( $p$-value $=0.003)$, occupation ( $p$-value $=0.015)$, presence of chronic illness ( $p$-value $=$ $0.035)$ were associated with practice against covid-19 infection. This is finding partly in line with the study conducted by Peeradone Srichan et al who showed age, gender, educational status, annual income as a factors for good practice. The type of analysis method used, Multivariate Vs. Bivariate, might be a reason for such difference[10].we found that educational level positively affect the practice of our respondents though Azlan AA et al.[16] Showed no effect. This difference could be due to variation in educational status categories.

\section{Conclusion}

We conclude that majority of responders have good attitude toward COVID-19 and its preventions. However, preventive measures of COVID-19 were practiced by only fewer respondents. Age, chronic medical illness, use of television as a source of information and level of knowledge are associated factors for level of attitude. Level of practice of preventive measures associated with educational status, occupation, presence of chronic medical illness and use of religious teaching as sources of information.

\section{Declarations}

\section{Ethical Approval and Consent to participate}

Ethical approval was received from Dilla University College of medicine and health science ethical review board

\section{Consent for publication}

Not applicable

\section{Availability of data and materials}

The datasets used or analyzed during the current study are available from the corresponding author on reasonable request

\section{Competing interest}

There is no competing interest to declare

\section{Funding}

Dilla University has funded the research project 


\section{Author's contributions}

Simeneh mola, Zemedu aweke, Bedru jemal and Robel Hussien contribute to study conception, design, data collection, and performed statistical analysis. Sileshi hailu, Derartu neme, Abebayehu zemedkun, Hailemariam Mulugeta contributed for interpretation of the result, writing up and prepared manuscript. All the authors read the manuscript and approved the final submission.

\section{Acknowledgements}

We would like to thank Dilla University College of Medicine and Health Science for funding this research.

\section{Abbreviations}

AOR

COVID-19

SARS-CoV-2

SPSS

USA

WHO
Adjusted odd ratio

Corona Virus 2019

Severe acute respiratory syndrome corona virus 2

Statistical Package for Social Science

united States of America

World health organization

\section{References}

1. Hussin A, Rothana SNB. The epidemiology and pathogenesis of coronavirus disease (COVID-19) outbreak. Journal of Autoimmunity, 2020. 109.

2. Shereen MA. COVID-19 infection: origin, transmission, and characteristics of human coronaviruses. J Adv Res. 2020;24:91-8.

3. WHO. Coronavirus disease 2019 (COVID-19) Situation Report - 138. WHO, 2020.

4. WHO. COVID-19: situation update for the WHO african region, external report 7WHO, 2020.

5. Marius Gilbert GP, Pinotti F. Preparedness and vulnerability of African countries against importations of COVID-19. lancet 2020. 395.

6. Martinez-Alvarez M. COVID-19 pandemic in west Africa. lancet 2020 8: p. 632.

7. $10.1101 / 2020.04 .21 .20064147$

Malik Sallam DD, Yaseen A. Conspiracy beliefs are associated with lower knowledge and higher anxiety levels regarding COVID-19 among students at the University of Jordan. doi: https://doi.org/10.1101/2020.04.21.20064147, 2020.

8. Policy Brief: Impact of COVID-19 in Africa. UN, 2020. 
9. WHO. COVID-19 BULLETIN ETHIOPIA MAR 27. WHO, 2020.

10. Covid-19 Pandemic Preparedness And Response In Ethiopia Public Health Emergency Operation Center (Pheoc), 2020, May 11. Weekly Buletin (2).

11. COVID-19 RESPONSE BULLETIN ETHIOPIA 04 APRIL WHO, 2020.

12. Notification note on additional COVID-19 Confirmed Cases: COVID-19 update Ethiopian public health institutes 2020, march 27.

13. Srichan P, et al., Knowledge, Attitude and Preparedness to Respond to the 2019 Novel Coronavirus (COVID-19) Among the Bordered Population of Northern Thailand in the Early Period of the Outbreak: A Cross-Sectional Study. pre-print SSRN Electronic Journal, 2020.

14. Erfani A, Knowledge, Attitude and Practice toward the Novel Coronavirus (COVID-19) Outbreak: $A$ Population-Based Survey in Iran. preprint 2020 http://dx.doi.org/10.2471/BLT.20.256651.

15. Megan L, Ranney MD, Griffeth V. Critical Supply Shortages - The Need for Ventilators and Personal Protective Equipment during the Covid-19 Pandemic. The New England Journal Of Medicine. 2020;382(18):41.

16. Arina A, Azlan MRH. Tham Jen Sern, Suffian Hadi Ayub,Emma Mohamad, Public knowledge, attitudes and practices towards COVID-19: A cross-sectional study in Malaysia. PLoS ONE. 2020;15(15):1-15.

17. Clements JM. Knowledge and behaviors toward COVID-19 among U.S. residents during the early days of the pandemic. JMIR Public Health Surveill, 2020. 6(2).

18. Abdur Rahman NJS. Knowledge, Attitude, and Preventive Practices toward COVID-19 among Bangladeshi Internet Users. Electronic Journal of General Medicine, 2020. 17(5). 